\title{
IMPLEMENTASI METODE DEMONSTRASI UNTUK MENINGKATKAN HASIL BELAJAR SENI RUPA DI KELAS IX.7 SMP NEGERI 21 PEKANBARU
}

\author{
Elindra \\ SMP Negeri 21 Pekanbaru \\ e-mail: elindrasuryati898@yahoo.com
}

\begin{abstract}
This study aims to determine the implementation of demonstration methods to improve art learning outcomes in the class IX.7 State Junior High School 21 Pekanbaru, which is held for 1 month. Subjects in this study were students Class IX.7 SMP Negeri 21 Pekanbaru. The number of students who made the subject of research as many as 41 students. The form of research is classroom action research. The instrument of this research consisted of performance instrument and data collection instrument in the form of observation sheet of teacher activity and student activity. Based on the analysis and interpretation of data can be concluded that the increase in student learning outcomes after implemented learning by using the method of demonstration. As it is understanding of students experienced an increase from before the PTK that is in classical completeness only reaches on 39.02 classical completeness but after implemented in the first cycle by using the demonstration method of meeting 1 increased to 75.61 then the classical completeness again increased in cycle II that is to achieve classical mastery $92.68 \%$ or can be said complete learning with all students are able to achieve the value of KKM.
\end{abstract}

Keywords - demonstration method, learning result, art

\begin{abstract}
Abstrak
Penelitian ini bertujuan untuk mengetahui implementasi metode demonstrasi untuk meningkatkan hasil belajar seni rupa di kelas IX.7 SMP negeri 21 Pekanbaru, yang dilaksanakan selama 1 bulan. Subjek dalam penelitian ini adalah siswa Kelas IX.7 SMP Negeri 21 Pekanbaru. Jumlah siswa yang dijadikan subjek penelitian sebanyak 41 orang siswa. Bentuk penelitian adalah penelitian tindakan kelas. Instrumen penelitian ini terdiri dari instrumen unjuk kerja dan instrumen pengumpulan data berupa lembar observasi aktivitas guru dan aktivitas siswa. Berdasarkan analisis dan interpretasi data dapat disimpulkan bahwa adanya peningkatan hasil belajar siswa setelah dilaksanakan pembelajaran dengan menggunakan metode demonstrasi. Sebagaiamana pemahaman siswa mengalami peningkatan dari sebelum dilaksanakan PTK yakni pada ketuntasan klasikal hanya mencapai pada ketuntasan klasikal 39.02 namun setelah dilaksanakan pada siklus I dengan menggunakan metode demonstrasi pertemuan 1 meningkat menjadi 75.61 kemudian ketuntasan klasikal kembali meningkat pada siklus II yakni mencapai ketuntasan klasikal menjadi 92,68\% atau dapat dikatakan pembelajaran tuntas dengan semua siswa mampu mencapai nilai KKM.
\end{abstract}

Kata kunci-Metode demonstrasi, hasil belajar, seni rupa

\section{PENDAHULUAN}

Pendidikan Seni Budaya dan Keterampilan diberikan di sekolah karena keunikan, kebermaknaan, dan kebermanfaatan terhadap kebutuhan perkembangan peserta didik, yang terletak pada pemberian pengalaman estetik dalam bentuk kegiatan berekspresi/berkreasi dan berapresiasi melalui pendekatan: "Belajar dengan seni," "Belajar melalui seni" dan "Belajar tentang seni." Peran ini tidak dapat diberikan oleh mata pelajaran lain.

Muatan seni budaya sebagaimana yang diamanatkan dalam Peraturan Pemerintah Republik Indonesia Nomor 19 tahun 2005 tentang Standar Nasional Pendidikan tidak hanya terdapat dalam 
satu mata pelajaran karena budaya itu sendiri meliputi segala aspek kehidupan. Dalam mata pelajaran Seni Budaya, aspek budaya tidak dibahas secara tersendiri tetapi terintegrasi dengan seni. Karena itu, mata pelajaran Seni Budaya pada dasarnya merupakan pendidikan seni yang berbasis budaya.

Berdasarkan hasil pengamatan di SMP Negeri 21 Pekanbaru, tentang hasil belajar siswa ternyata masih ada beberapa siswa yang mendapatkan nilai dibawah KKM. Hal ini berarti hasil belajar siswa belum memuaskan, salah satu faktor yang mempengaruhinya adalah guru cendrung menggunakan metode ceramah, siswa kurang aktif dalam belajar, siswa pasif dalam belajar. Hal inilah yang menyebabkan kemampuan siswa tidak berkembang. Upaya guru untuk meningkatkan kemampuan siswa dalam menari, guru mencoba menerapkan metode demontrasi yang lebih kreatif dalam proses pembelajaran di kelas.

Berdasarkan penjelasan masalah diatas, maka perlu dilakukan upaya membangkitkan semangat siswa terhadap pembelajaran seni rupa sehingga terjadi perubahan proses belajar mengajar dalam hal ini perlu adanya perbaikan salah satu yaitu dengan menerapkan metode demonstrasi. Metode demonstrasi adalah salah suatu metode pembelajaran yang menekankan suatu upaya dengan menggunakan peragaan atau praktek sehingga siswa lebih mudah memahami dan mempraktekkan dari apa yang telah diajarkan guru kepadanya. Metode demonstrasi sangat diperlukan dalam proses pembelajaran kegiatan pembelajaran seni rupa karena tanpa metode demonstrasi yang tepat maka siswajuga akan kesulitan dalam memahami pembelajaran, dan seorang guru harus mampu berpikir bagaimana cara supaya peserta didik menjadi lebih mudah untuk memahami materi pelajaran yang dismapaikan, dibutuhkan metode demontrasi yang tepat dan sesuai dengan kondisi siswa dan lingkungan siswa.

Metode demostrasi baik digunakan untuk mendapatkan gambaran yang lebih jelas tentang hal-hal yang berhubungan dengan proses mengatur sesuatu, proses membuat sesuatu, proses bekerjanya sesuatu, proses mengerjakan atau menggunakannnya, komponen-komponen yang membentuk sesuatu, membandingkan suatu cara dengan cara lain, dan untuk mengetahui atau melihat kebenaran sesuatu.

Berdasarkan hasil penelitian ditemukan bahwa siswa yang diajarkan menari dengan menggunakan metode demonstrasi ternyata memiliki kemampuan yang lebih baik dibandingkan sebelum siswa diajarkan dengan metode demonstrasi.

Sehubungan dengan hal diatas, penulis merasa tertarik melakukan penelitian yang berjudul "Implementasi Metode Demonstrasi Untuk Meningkatkan Hasil Belajar Seni Rupa di Kelas IX.7 SMP Negeri 21 pekanbaru".

\section{METODE}

Tempat penelitian ini dilaksanakan di kelas IX.7 SMP Negeri 21 Pekanbaru. Subjek penelitian adalah siswa kelas IX.7 yang berjumlah 41 orang

Menurut Usman (2009:41), metode penelitian adalah suatu prosedur atau cara untuk mengetahui sesuatu yang mempunyai langkah sistematis. Sedangkan metodologi penelitian adalah suatu pengkajian dalam mempelajari peraturan-peraturan yang terdapat pada penelitian.

Dalam hal ini penulis menggunakan Penelitian Tindakan Kelas (PTK). Penelitian tindakan kelas adalah suatu usaha yang dilakukan pendidik untuk apa yang terdapat pada kelas dan mencari solusi yang tepat untuk mengatasi masalah tersebut. Menurut Mc Taggart dalam Suryawati (2009: 8) penelitian tindakan kelas terdiri atas empat tahap yaitu:

\section{a. Penyusunan Rencana}

Rencana adalah tahap awal yang harus dilakukan sebelum melakukan PTK dengan perencanaan yang baik seorang praktisi akan lebih mudah untuk mengatasi kesulitan dan mendorong praktisi untuk bertindak dengan lebih efektif.

b. Tindakan

Tindakan adalah suatu penerapan dari rencana yang telah dilakukan dapat berupa suatu penerapan model pembelajaran tertentu yang bertujuan memperbaiki model yang sedang dijalankan. 
c. Observasi

Observasi berfungsi untuk melihat dan mendokumentasikan pengaruh yang diakibatkan oleh tindakan didalam kelas. Hasil observasi merupakan dasar dilakukannya refleksi sehingga yang dilakukan harus dapat menggambarkan keadaan yang sesungguhnya.

d. Refleksi

Refleksi disini meliputi kegiatan analisi, sintesis, penafsiran, menjelaskan dan menyimpulkan. Hasil dari refleksi adalah diadakannya revisi terhadap perencanaan yang telah dilaksanakan dan digunakan untuk memperbaiki kinerja pada pertemuan selanjutnya.

Untuk mendapatkan data untuk kepentingsn peneliti, maka peneliti menggunakan teknik pengumpulan data yang terdiri dari:

a. Teknik Observasi

Menurut Usman (2009:52) observasi adalah pengamatan dan pencatatan yang sistematis terhadap gejala yang diteliti. Observasi menjadi salah satu teknik pengumpulan data apabila sesuai dengan tujuan penelitian, direncanakan dan dicatat secara sistematis, serta dapat dikontrol keandalan (realibilitas) dan keahliannya (validitasnya).

b. Teknik Praktek

Teknik praktek ini bertujuan untuk Meningkatkan Hasil Belajar Seni rupa di Kelas IX.7 SMP Negeri 21 Pekanbaru. Dalam praktek ini setiap kelompok siswa diinstruksikan untuk menunjukkan hasil karya seni rupa.

c. Teknik Dokumentasi

Usman (2009:69) mengatakan teknik pengumpulan data dengan dokumentasi adalah pengambilan data yang diperoleh melalui dokumen. Menurut Iskandar (2008:219) dokumen yang dimaksud adalah dokumen resmi seperti refrensi dan foto. Teknik dokumentasi ini dilakukan dengan kamera atau handphone.

\section{Teknik Analisis Data}

Sri Rezeki (2009:17) menyatakan untuk mengetahui ketuntasan individu siswa dari hasil belajar di hitung dengan menggunakan rumus sebagai berikut:

$\begin{aligned} \text { Ketuntasan Individu } & =\frac{\text { Skor Hasil Belajar Siswa }}{\text { Skor Maksimal Penilaian }} \times 100 \% \\ \text { Ketuntasan Klasikal } & =\frac{\text { Jumlah Siswayang Tuntas }}{\text { Jumlah Seluruh Siswa }} \times 100 \%\end{aligned}$

\begin{tabular}{|c|c|}
\hline Interval & Kategori \\
\hline $95-100$ & SANGAT BAIK \\
\hline $85-94$ & Baik \\
\hline $76-84$ & Cukup \\
\hline$\leq 75$ & Kurang \\
\hline
\end{tabular}

Sumber: disesuaikan dengan KKM mata Pelajaran seni budaya

\section{HASIL DAN PEMBAHASAN}

\section{Rekapitulasi Aktivitas Guru dalam Upaya Meningkatkan Hasil Belajar Siswa dalam Pembelajaran Seni Rupa dengan Menggunakan Metode Demonstrasi Siswa Kelas IX.7 SMP Negeri 21 Pekanbaru}

Keberhasilan siswa dalam pembelajaran sangat dipengaruhi oleh aktivitas guru pada saat pembelajaran. berdasarkan data yang diperoleh dari hasil observer sebagaimana penulis diskripsikan maka perkembanagan aktivitas guru dalam pembelajaran dnegan menggunakan Metode Demonstrasi dalam pembelajaran seni rupa Siswa Kelas IX.7 SMP Negeri 21 Pekanbaru dapat dikatakan setiap siklus dan setiap pertemuan berbeda peningkatannya, hal ini ditunjukan 
pada siklus I dan siklus II pada pertemuan I adalah mencapai persentase $56.0 \%$, pertemuan II mencapai $68.0 \%$, pada pertemuan III mencapai $84.0 \%$, pada pertemuan IV meningkat menjadi $96.0 \%$, dengan hal ini menunjukan bahwa dalam setiap pertemuan aktivitas guru mengalami peningkatan yang labih baik, untuk lebih jelasnya dapat dilihat sebagai berikut:

Tabel 1. Rekapitulasi persentase aktivitas guru

\begin{tabular}{|c|c|c|c|c|c|}
\hline \multirow{2}{*}{ No } & \multirow{2}{*}{ Aktivitas yang diamati } & \multicolumn{2}{|c|}{ SIKLUS I } & \multicolumn{2}{|c|}{ SIKLUS II } \\
\hline & & Pert I & Pert 2 & Pert I & Pert 2 \\
\hline 1 & Guru menjelaskan tujuan pembelajaran & 4 & 4 & 5 & 5 \\
\hline 2 & $\begin{array}{l}\text { Guru mengarahkan langkah-langkah } \\
\text { yang akan digunakan dalam } \\
\text { pembelajaran }\end{array}$ & 3 & 4 & 4 & 5 \\
\hline 3 & Guru menjelaskan mataeri pembelajaran & 3 & 3 & 4 & 5 \\
\hline 4 & $\begin{array}{l}\text { Guru berusaha menumbuhkan sikap } \\
\text { kritis dan berani bertanya }\end{array}$ & 3 & 3 & 3 & 4 \\
\hline 5 & $\begin{array}{l}\text { Guru mendemontrasikan materi } \\
\text { pelajaran seni rupa }\end{array}$ & 3 & 4 & 5 & 5 \\
\hline 6 & $\begin{array}{l}\text { Guru mengarahkan siswa untuk } \\
\text { berdiskusi dalam kelompok }\end{array}$ & 3 & 3 & 5 & 5 \\
\hline 7 & $\begin{array}{l}\text { Guru mengarahkan siswa untuk } \\
\text { mendemontrasikan hasil diskusi } \\
\text { kelompok }\end{array}$ & 2 & 3 & 3 & 4 \\
\hline 8 & $\begin{array}{l}\text { Guru memberikan pertanyaan untuk } \\
\text { mengetahui pemahaman siswa }\end{array}$ & 2 & 3 & 5 & 5 \\
\hline 9 & $\begin{array}{l}\text { Guru memberikan keterangan yang } \\
\text { sebenarnya dari jawaban siswa }\end{array}$ & 2 & 3 & 4 & 5 \\
\hline 10 & $\begin{array}{l}\text { Guru memberikan kesimpulan hasil } \\
\text { pembelajaran }\end{array}$ & 3 & 4 & 4 & 5 \\
\hline & Jumlah & 28 & 34 & 84 & 48 \\
\hline & Persentase & 56.0 & 68.0 & 84.0 & 96.0 \\
\hline
\end{tabular}

\section{Rekapitulasi Aktivitas Siswa dalam Meningkatkan Hasil Belajar Siswa Pembelajaran Seni Rupa Dengan Menggunakan Metode Demonstrasi Siswa Kelas IX.7 SMP Negeri 21 Pekanbaru}

Keberhasilan siswa dalam pembelajaran sangat dipengaruhi oleh aktivitas guru pada saat pembelajaran. berdasarkan data yang diperoleh dari hasil observer sebagaimana penulis diskripsikan maka perkembanagan aktivitas siswa dalam pembelajaran dengan menggunakan metode demonstrasi dalam pembelajaran seni rupa Siswa Kelas IX.7 SMP Negeri 21 Pekanbaru dapat dikatakan setiap siklus dan setiap pertemuan berbeda peningkatannya, hal ini ditunjukan pada siklus I dan siklus II pada pertemuan I adalah mencapai persentase 52.7, pertemuan II mencapai 62.7, pada pertemuan III mencapai 76.8 , pada pertemuan IV kembali meningkat menjadi 86.6, dengan hal ini menunjukan bahwa dalam setiap pertemuan aktivitas siswa mengalami peningkatan yang labih baik, untuk lebih jelasnya dapat dilihat sebagai berikut:

Tabel 2. Rekapitulasi persentase aktivitas siswa

\begin{tabular}{|c|c|c|c|c|c|}
\hline \multirow[b]{2}{*}{ No } & \multirow[b]{2}{*}{ Aktivitas yang diamati } & \multicolumn{2}{|c|}{ SIKLUS I } & \multicolumn{2}{|c|}{ SIKLUS II } \\
\hline & & Pert I & Pert 2 & Pert I & Pert 2 \\
\hline 1 & Siswa mendengarkan tujuan pembelajaran & 61.0 & 70.7 & 80.5 & 95.1 \\
\hline 2 & $\begin{array}{l}\text { Siswa memperhatikan langkah-langkah } \\
\text { pembelajaran yang dilaksanakan }\end{array}$ & 46.3 & 68.3 & 78.0 & 82.9 \\
\hline 3 & Siswa mendengarkan mataeri pembelajaran & 53.7 & 58.5 & 75.6 & 92.7 \\
\hline 4 & $\begin{array}{l}\text { Siswa berusaha untuk bersikap kritis dan berani } \\
\text { bertanya }\end{array}$ & 34.1 & 61.0 & 73.2 & 92.7 \\
\hline 5 & $\begin{array}{l}\text { Siswa memperhatikan demontrasi materi pelajaran } \\
\text { seni rupa }\end{array}$ & 56.1 & 63.4 & 73.2 & 85.4 \\
\hline 6 & Siswa berdiskusi dalam kelompok & 56.1 & 58.5 & 75.6 & 85.4 \\
\hline 7 & Siswa mendemontrasikan hasil diskusi kelompok & 53.7 & 65.9 & 80.5 & 75.6 \\
\hline 8 & Siswa mengajukan pertanyaan & 58.5 & 61.0 & 80.5 & 90.2 \\
\hline 9 & $\begin{array}{l}\text { Siswa mendengarkan keterangan yang sebenarnya } \\
\text { dari guru }\end{array}$ & 56.1 & 63.4 & 78.0 & 90.2 \\
\hline 10 & Siswa mencatat kesimpulan hasil pembelajaran & 51.2 & 56.1 & 73.2 & 75.6 \\
\hline & Jumlah & 526.8 & 626.8 & 768.3 & 865.9 \\
\hline & Persentase & 52.7 & 62.7 & 76.8 & 86.6 \\
\hline
\end{tabular}


Berdasarkan tabel diatas menunjukan peningkatan dalam setiap pertemuannya aktivitas siswa. Maka dalam hal ini adanya peningkatan dalam setiap aktivitas siswa maupun guru dalam setiap pembelajaran dengan menggunakan Metode Demonstrasi, sehingga mengakibatkan hasil pemahaman siswa juga baik seecara teori maupun praktek.

\section{Rekapitulasi Hasil Belajar Siswa Pada Pelajaran Seni rupa dengan Menggunakan} Metode Demonstrasi Siswa Kelas IX.7 SMP Negeri 21 Pekanbaru

Hasil belajar siswa sangat dipengaruhi oleh aktivitas siswa pada saat pembelajaran. Berdasarkan data yang diperoleh dari hasil observer sebagaimana penulis diskripsikan maka hasil belajar siswa dengan menggunakan metode demonstrasi dalam pembelajaran seni rupa Siswa Kelas IX.7 SMP Negeri 21 Pekanbaru dapat dikatakan setiap siklus dan setiap pertemuan berbeda peningkatannya, hal ini ditunjukan mulai dari data awal, pada siklus I dan siklus II. Pada data awal diperoleh nilai rata-rata 70,2 dengan nilai ketuntasan 39,02. Sedangkan pada siklus I nilai rata-rata 80,5 dengan nilai ketuntasan 75,61 dan pada siklus II diperoleh nilai rata-rata 84,6 dengan nilai ketuntasan 92,68, untuk lebih jelasnya dapat dilihat grafik berikut:

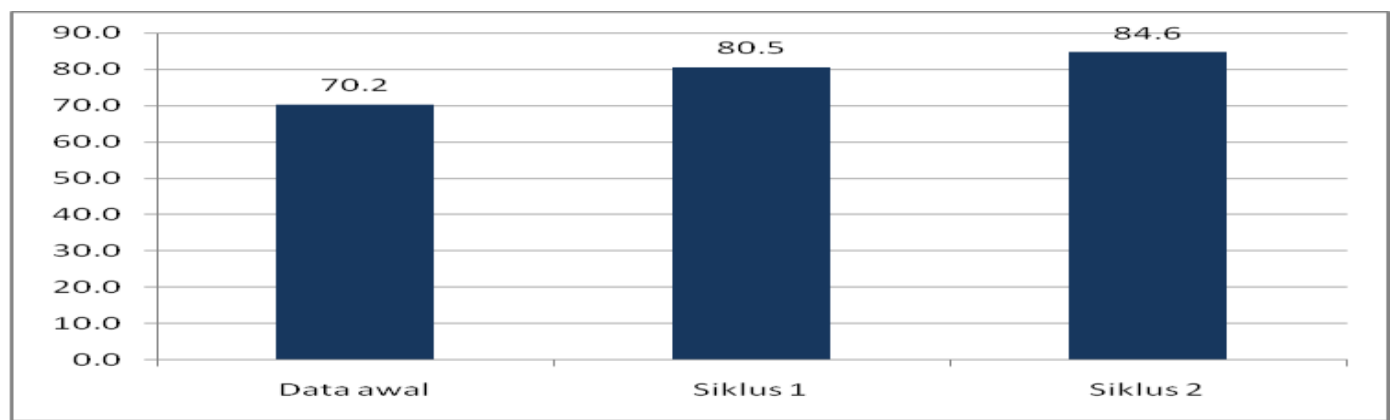

Gambar 1. Grafik Hasil Belajar Siswa

\section{KESIMPULAN}

Berdasarkan analisis dan interpretasi data dapat disimpulkan bahwa adanya peningkatan hasil belajar siswa setelah dilaksnakan pembelajaran dengan menggunakan metode demonstrasi. Sebagaiamana pemahaman siswa mengalami peningkatan dari sebelum dilaksanakan PTK yakni pada ketuntasan klasikal hanya mencapai pada ketuntasan klasikal 39.02 namun setelah dilaksanakan pada siklus I dengan menggunakan metode demonstrasi pertemuan 1 meningkat menjadi 75.61 kemudian ketuntasan kalsikal kembali meningkat pada siklus II yakni mencapai ketuntasan klasikal menjadi 92,68\% atau dapat dikatakan pembelajaran tuntas dengan semua siswa mampu mencapai nilai KKM.

\section{SARAN}

Berdasarkan hasil penelitian dan analisis data yang telah dilaksanakan, maka peneliti mengaju beberapa saran.

1. Kepada peneliti hendaknya dapat memberikan kejelasan tentang tes hasil belajar yang akan di berikan kepada siswa sehingga siswa akan mudah memahami maksud dalam pertanyaan dalam tes tersebut.

2. Kepada guru seni budaya hendaknya dapat menggunakan metode-metode yang baru sehingga akan dapat membantu dan mempermudah tercapainya tujuan pembelajaran.

\section{DAFTAR PUSTAKA}

[1] Arikunto, Suharsimi. 2006. prosedur Penelitian (Suatu Pendekatan Praktek). Jakarta: Rineka Cipta.

[2] Bastomi. 1985. Berapresiasi Pada Seni Rupa. Semarang: Universitas Negeri Semarang Press. 
[3] Hardini, Isriani. 2012. Strategi Pembelajaran Terpadu. Yogyakarta. Group Relasi Inti Media.

[4] Hamdani. 2011. Strategi Belajar Mengajar. Bandung: Remaja Rosda Karya.

[5] Djamarah, Syaiful Bahri, dkk, 2006, "Strategi Belajar Mengajar”, Jakarta, Rineka cipta.

[6] Iskandar. 2008. Metodologi Penelitian Pendidian dan Sosial (Kuantitatif dan Kualitatif). Jakarta: Rineka Cipta.

[7] Ngalim Purwanto 2003 . Psikologi Pendidikan. Bandung: Remaja rosdakarya

[8] Nunuk Suryani. 2012. Strategi Bwlajar Mengajar. Yogyakarta: Penerbit Ombak.

[9] Peraturan Menteri Pendidikan Kebudayaan Republik Indonesia. Nomor 81A Tahun 2005

[10] Rondhi, Moh. dan Anton Sumartono. 2002. Tinjauan Seni Rupa 1. Semarang: Universitas Negeri Semarang.

[11] Slameto, 2010. Belajar dan Faktor-faktor yang Mempengaruhinya. Jakarta: Rineka Cipta.

[12] Sunaryo, Aryo. 2002. Nirmana I. Semarang: Universitas Negeri Semarang

[13] Tim Abdi Guru. 2007. Seni Budaya SMP Kelas VII. Demak: Erlangga

[14] Udin S. Winataputra. 2001.Srategi Belajar Mengajar. Pusat Penerbitan: Universitas Terbuka 